\title{
- ESTABELECIMENTO \\ DO EXCLUSIVO \\ COMERCIAL \\ METROPOLITANO E \\ A CONFORMAC̣ÃO \\ DO ANTIGO SISTEMA \\ COLONIAL NO BRASIL
}

\section{Rodrigo}

\section{RICUPERO}

Professor no Departamento de História da FFLCH/USP ricupero@usp.br

The establishment of Exclusive Metropolitan Trade and the formation of the Old Colonial System in Brazil

\section{RESUMO}

O exclusivo metropolitano, peça-chave do sistema colonial, foi estabelecido no Brasil entre o final do século XVI e o início do século XVII. $O$ presente artigo procura rastrear a evolução das disposições legais sobre o comércio com o estrangeiro no Brasil, bem como as ideias que nortearam a adoção da proibição de tal comércio no período e o impacto de tal decisão.

Palavras-chave: Sistema Colonial, Brasil Colonial, Exclusivo metropolitano.

\begin{abstract}
The metropolitan exclusive, key piece of the colonial system, was established in Brazil between the end of the XVI century and the early XVII century. This article attempts to trace the evolution of the legal provisions on trade with the Foreigner in Brazil, as well as the ideas that guided the adoption of the ban on such trade in these period and the impacto of such a decision.
\end{abstract}

Keywords: Colonial System, Colonial Brazil, Metropolitan Exclusive. 

regente $\mathrm{D}$. João, o futuro $\mathrm{D}$. João $\mathrm{VI}$, assinava uma pequena carta dirigida ao governador da Bahia, o Conde da Ponte, estabelecendo a abertura dos portos do Brasil, com a suspensão temporária de "todas as leis, cartas régias ou outras ordens, que até aqui proibiam neste Estado do Brasil o recíproco comércio e navegação entre meus vassalos e estrangeiros". ${ }^{2}$

Episódio conhecido, a vinda da família real para o Brasil dispensa maiores comentários. ${ }^{3}$ Registre-se apenas que, com a invasão e ocupação de Portugal pelas tropas francesas, todo navio que fosse enviado ao reino seria provavelmente confiscado pelo inimigo, e, por outro lado, com a instalação da Corte no Rio de Janeiro, era preciso garantir o suprimento dos gêneros importados, bem como manter a arrecadação, em grande medida gerada pelo comércio exterior, necessária ao funcionamento da máquina estatal. Neste sentido, a abertura dos portos seria praticamente inevitável.

A própria carta régia apresenta essa justificativa, contida em uma representação do Conde da Ponte, por "se achar interrompido e suspenso o comércio desta capitania [Bahia], com grave prejuízo dos meus vassalos e da minha Real Fazenda, em razão das críticas e públicas circunstâncias da Europa" (BIKER, 1878, p. 102). A solução encontrada foi a permissão temporária (na prática, definitiva) do comércio direto com o estrangeiro, prescindido da escala metropolitana, encerrando o assim chamado exclusivo metropolitano do comércio colonial no Brasil, ${ }^{4}$ mas não a polêmica entre seus defensores e detratores, que iria se manter, ainda que em outros termos, até a Independência. ${ }^{5}$

Peça importante do debate, o livro Observações sobre o comércio franco no Brasil, de José da Silva Lisboa, futuro Visconde de Cairu, ${ }^{6}$ publicado pela Imprensa Régia entre 1808 e 1809 (LISBOA, 1993 [1808/9]; ROCHA, 2001 [1808/9]), ajuda a situar os termos da polêmica - a necessidade ou não da medida e se esta deveria continuar em vigor com a restauração do reino - e ainda nos permite conhecer as críticas que circularam contra o fim do exclusivo comercial metropolitano.

Escrita rapidamente, a obra é uma defesa da Coroa portuguesa, ${ }^{7}$ da aliança inglesa e da abertura dos portos sempre no melhor espírito liberal e valendo-se, em especial, dos escritos de Adam Smith. Era dirigida contra aqueles que, nas palavras do autor, "se atrevem a espalhar no vulgo zizânias perniciosas e impolíticas" (ROCHA, 2001 [1808/9], p. 209) sem, contudo, nomear qualquer opositor. Estes, ao que tudo indica, eram em particular os comerciantes interessados na manutenção do monopólio comercial e hostis a qualquer mudança do status quo mercantil. ${ }^{8}$

No melhor estilo áulico, Cairu não poupa os maiores elogios à Coroa portuguesa e ao príncipe regente, proclamando-o, por exemplo, como "libertador do comércio", embora, ao descrever a abertura dos portos, oscile ora como uma "incomparável mercê", ora como "inevitável necessidade política". 9 
O Visconde de Cairu faz na segunda parte do trabalho uma defesa apaixonada, e algumas vezes mesmo ingênua, da Inglaterra. ${ }^{10}$ Esta era sempre vista como grande aliada e parceira comercial. Para ele, "se a franqueza do comércio com todas as nações é útil no Brasil, ela é imprescindível com os ingleses, por necessidade, interesse, política, e gratidão nacional" (ROCHA, 2001 [1808/9], p. 54). O autor, dessa forma, tentava refutar as críticas feitas, pelo que poderíamos denominar como uma corrente de opinião pública anti-inglesa que questionava as vantagens de tal aliança, ${ }^{11}$ acusando, nas palavras registradas por Cairu, os ingleses de "estender cada vez mais o seu sistema de colonizar o mundo inteiro, para extraírem as riquezas dos povos, impossibilitar-lhes a indústria, e constituí-los em perpétua dependência de seus suprimentos" (ROCHA, 2001 [1808/9], p. 195).

Seria, contudo, na terceira parte da obra que o autor concentraria os argumentos a favor da abertura dos portos, tentando refutar, nem sempre de forma convincente, as críticas que ele próprio arrolara em seis itens: a questão da saída do dinheiro e dos metais preciosos, o perigo de os estrangeiros monopolizarem o comércio do país, o risco para a marinha e indústria, o sacrifício da metrópole a favor da colônia, a falta de reciprocidade nas relações comerciais e a falta de exemplo semelhante na política das demais potências (ROCHA, 2001 [1808/9], p. 123).

Vejamos em particular o sexto e último item: "Tal política não se funda em prática das nações da Europa, e nem ainda da Inglaterra, que sempre insiste no antigo sistema colonial" (ROCHA, 2001 [1808/9], p. 172). No diálogo imaginário apresentado por Cairu, "alguns triunfam com o exemplo de Inglaterra, que não obstante as doutrinas de Smith, pratica o mesmo que a França, sustentando monopólios, autorizando companhias exclusivas e conservando o sistema colonial" (ROCHA, 2001 [1808/9], p. 182).

A tal objeção Cairu responderia, em primeiro lugar, com a singularidade da situação, para depois lançar mão do receituário liberal contra os monopólios em geral. Clamando "graças ao céu! Tirou-se das colônias o que Smith chama peso morto e grilhão", Cairu enfatizaria que "tornar-se a pôr aquele peso e grilhão seria organizar a pobreza e imbecilidade da monarquia, abandonando-a à mercê de monopolistas, e inimigos" (ROCHA, 2001 [1808/9], p. 182).

Adam Smith não foi o primeiro a criticar o sistema colonial, mas, a partir de seu ponto de vista, desferiu um poderoso ataque, sobretudo por direcionar suas baterias nas implicações econômicas da colonização (ROCHA, 2001 [1808/9], p. 202-203). Smith, em uma passagem evocada por Cairu, sintetizaria sua crítica ao exclusivo comercial ao afirmar que o exclusivo comercial das metrópoles, pelo imaginário benefício das metrópoles, cria obstáculos à atividade de todos os outros países e à das próprias colônias, pois exclui, na medida do possível, todos os outros países do mercado das colônias e as limita a um mercado particular. Por fim, enfatizaria: "a diferença é muito grande entre ser excluído de um particular mercado, quando todos os outros estão abertos, e ser restrito a um particular mercado, quando todos os outros estão fechados" (ROCHA, 2001 [1808/9], p. 202-203; 
SMITH, 1958 [1776], p. 527-528).

Independentemente da opinião positiva ou negativa sobre o exclusivo metropolitano, a realidade, como Smith atestava, é que todas as nações europeias procuravam monopolizar o comércio das suas colônias, proibindo o comércio "aos barcos de outros países" e ainda que os colonos "importem outros produtos que não sejam dos da metrópole, a não ser que estas operações se façam por sua mediação" (SMITH, 1958 [1776], p. 512).

Em outras palavras, o exclusivo comercial era a proibição legal do comércio entre as colônias e as nações estrangeiras, seja através de barcos ou de mercadores dessas nações, seja através de barcos ou de mercadores nacionais que partissem das colônias em direção a outros países. Tanto na ida às colônias, como na volta delas a escala metropolitana era indispensável. Evidentemente que no tempo e no espaço tal mecanismo foi mais ou menos restrito (Cf. NOVAIS, 1995, p. 72; BROUGHAM, 1803). Permissão de comércio apenas em determinados portos, companhias comerciais privilegiadas, regime de frotas foram, entre outros, alguns dos recursos utilizados; por outro lado, em alguns momentos, o exclusivo poderia ser atenuado em virtude de situações específicas, como, por exemplo, guerras que dificultassem ou impedissem o comércio ou com a concessão de licenças especiais para mercadores estrangeiros por motivos econômicos ou diplomáticos. ${ }^{12}$

O monopólio do comércio justificava-se pela compreensão do papel das colônias que foi se conformando entre os séculos XV e XVIII, articulando-se com o pensamento econômico dominante e que acabaria por moldar as bases teóricas do sistema colonial mercantilista. ${ }^{13}$

Tal compreensão encontraria no verbete "Colônia" da Encyclopédie, publicado em 1753, uma síntese magistral. Partindo da ideia de que as colônias tinham sido estabelecidas "para utilidade da metrópole" e que, consequentemente, seu comércio deveria ser "exclusivo dos [seus] fundadores", a ponto de considerar-se, no caso de comércio com estrangeiros ou de consumo de mercadorias estrangeiras, que a "soma total desse comércio e dessas mercadorias [seria] um roubo feito à metrópole". A utilidade das colônias, neste sentido, se daria com o consumo dos produtos agrícolas e manufaturados metropolitanos, com o fornecimento dos gêneros e matérias-primas que não poderiam ser obtidos na própria metrópole e com os excedentes deste comércio que, por sua vez, poderiam ser reexportados para outros países (M. V. D. F. [Farbonnais], 1753). ${ }^{14}$

O exclusivo comercial metropolitano constituía-se assim, para usar as palavras de Fernando Novais, no "mecanismo por excelência do sistema" (NOVAIS, 1995, p. 72) e tal já era a compreensão na época. Para Hipólito da Costa, comentando a obra de Cairu, a abertura dos portos pôs "fim ao sistema de governo colonial antigo" (CORREIO BRAZILIENSE, 2001 [1808-1822], p. 476); já Cairu, mais fiel aos termos da carta de 28 de janeiro, optou por falar em "suspensão" do sistema colonial. ${ }^{15}$

Portanto, se até aqui vimos que o exclusivo metropolitano era a base fundamental em 
que se assentava o sistema colonial e que, no caso da relação de Portugal com o Brasil, ele se encerra em 1808, podemos então colocar uma nova questão: quando começou a vigorar o exclusivo metropolitano e, portanto, o próprio sistema colonial?

No começo do século XIX, o futuro Visconde de Cairu, em seu trabalho "Memória dos benefícios políticos do governo de El-Rey Nosso Senhor D. João VI", de 1818, esboçou uma resposta. Para ele, ainda no sentido de enaltecer a ação do então príncipe regente, era a abertura dos portos contrária "ao acordo das potências, que, no Congresso de Utrecht (1713-1715), haviam firmado o Sistema Colonial, vedando entre si o comércio de seus Estados Ultramarinos, estabelecendo o monopólio das metrópoles" (LISBOA, 1940 [1818], p. 67).

Tal explicação para as origens do exclusivo metropolitano, ainda que curiosa, é evidentemente equivocada. Os vários tratados entre as potências assinados em Utrecht, quando tratavam da questão, simplesmente referendavam as disposições então existentes sobre o comércio com as colônias, e, ainda que introduzissem alguma concessão, não alteraram o quadro vigente. ${ }^{16}$

Recuando para o século XVIII, o Marquês de Pombal apresentaria uma resposta a nossa questão muito mais elaborada. Esta apareceria em 1772, em uma peça que serviria de resposta à reclamação do enviado inglês em Lisboa, Robert Walpole, que protestava contra a apreensão de um navio inglês no Rio de Janeiro. ${ }^{17}$ Para Pombal, o caso da apreensão do navio em si era secundário, mais importante era aproveitar a ocasião para defender o exclusivo português e, assim, excluir "os ingleses e franceses dos portos do Brasil, que já se iam acostumando a tomar por escala de sua navegação da Índia". Para isso, em sua resposta, apresenta um largo estudo da questão da proibição do comércio estrangeiro nas conquistas portuguesas. Para tanto valer-se-ia, para isso, não apenas da legislação portuguesa e estrangeira e de tratados firmados pela Coroa de Portugal, mas também de autores de várias nacionalidades que trataram da questão, cujas ideias conformariam uma espécie de fundamentação teórica para as leis citadas. ${ }^{18}$

O Marquês de Pombal procurava, para defender a apreensão do navio inglês, mostrar, em primeiro lugar, o caráter geral do exclusivo metropolitano, pois "sendo sempre da mesma natureza intrínseca das colônias ultramarinas de todas as nações não haver nelas navegação e comércio senão com as suas respectivas metrópoles"19 e, em segundo lugar, sua antiguidade, afinal tais leis não eram modernas, mas, pelo contrário, "tão antigas que nos domínios ultramarinos de Portugal foram e são fundamentais desde o estabelecimento das primeiras colônias portuguesas" nos reinados de Dom Afonso V e de Dom João II no século XV. ${ }^{20}$

A partir daí tais leis seriam inseridas nas ordenações manuelinas e filipinas, confirma- 
das nas cortes de Tomar em 1580, e, segundo o esquema de Pombal, teriam prevalecido sempre, "pelo mesmo motivo de serem fundamentais", ${ }^{21}$ inclusive contra os tratados de navegação e de comércio, ratificados no século XVII com a Holanda e a Inglaterra, "em que se estipulou o contrário" e, por fim, confirmadas nos tratados assinados em Utrecht entre 1713 e 1715. Dessa forma, Pombal sentenciava, "não podia haver, nem com efeito houve, navegação e comércio" entre Portugal e as colônias inglesas, nem entre a Inglaterra e as portuguesas "nos cento e dezoito anos que decorrem desde o de 1654 em que se assinou o tratado com Olivério Cromwell [sic]".

Reforçando esta concepção, três anos antes, o irmão de Pombal, Francisco Xavier de Mendonça Furtado, então Secretário de Estado dos Negócios Ultramarinos, enviara uma carta ao Marquês do Lavradio, Vice-Rei do Brasil, sobre a proibição do comércio feito por navios estrangeiros conforme as leis e ordens régias. Para auxiliar o cumprimento da tarefa, "ordenou Sua Majestade se procurassem as ditas leis e ordens, que proíbem aos navios estrangeiros [...] entrar nos portos do Brasil. Delas se fez uma coleção" para enviar ao Vice-rei e demais governadores. ${ }^{22}$ Tal coleção começava com as Ordenações Filipinas, que no caso registra uma lei que já constava das Ordenações Manuelinas, ${ }^{23}$ e seguia com leis dos séculos XVI, XVII e, em muito maior número, XVIII, perfazendo, no total, quarenta documentos. ${ }^{24}$ Dessa forma, o início do exclusivo colonial teria ocorrido em fins do século XV.

A princípio, como veremos adiante, tal ideia também poderia parecer referendada pelas informações fornecidas por D. Fernando José de Portugal em 1806, na altura Vice-rei do Brasil, nos seus comentários ao "Regimento do Governo-Geral do Estado do Brasil dado ao mestre de campo Roque da Costa Barreto". ${ }^{25}$ Afinal, D. Fernando José de Portugal afirmava que "a mais antiga que encontro, é o alvará de 1591, que determinava que nenhum navio estrangeiro pudesse ir às conquistas do Brasil e da Costa da África", com a perda do navio, mercadorias e punição dos transgressores, conforme as penas contidas nas Ordenações Manuelinas (MENDONÇA, 1972, p. 822) e, assim, retornaríamos, na busca das origens do exclusivo metropolitano, ao século XV.

Na verdade, o Marquês de Pombal, ao fazer retroceder a proibição do comércio estrangeiro para o século XV, provocava, deliberadamente ou enganado, uma enorme confusão, pois se era certa a existência de leis que proibiam o comércio e a navegação de estrangeiros nas áreas dos descobrimentos portugueses, é certo também que tais leis não foram aplicadas ao Brasil depois da criação das chamadas capitanias hereditárias, como vamos provar adiante.

O fato é que, durante os séculos XV e XVI, desenvolveu-se em Portugal a doutrina sobre o monopólio do direito à navegação e, consequentemente, do comércio nas áreas "descobertas" pelos portugueses. ${ }^{26} \mathrm{Em}$ 1554, D. João III sintetizou a questão da seguinte forma, os mares "que todos devem e podem navegar são aqueles que sempre foram sabidos de todos e comuns a todos, mas os outros, que nunca foram sabidos nem parecia que se podiam navegar e foram descobertos com tão grandes trabalhos por mim, esses não". ${ }^{27}$ 
Questionada pelas demais nações europeias, na teoria e na prática, tal doutrina teve de ser defendida com armas e com plumas. Neste último caso, como, por exemplo, João de Barros, em sua grande obra conhecida como Décadas da Ásia, sintetizaria a questão na passagem em que explicava os motivos por que D. Manuel teria incorporado ao seu título o de "Senhor da Conquista, Navegação e Comércio da Etiópia, Arábia, Pérsia e Índia". ${ }^{28}$ João de Barros afirmava que D. Manuel primeiro descobriu a navegação, tomando posse desse caminho, e depois as terras habitadas, que, por serem de mouros e gentios idólatras, poderiam ser conquistadas como de "injustos possuidores, por negarem a gloria que devem a seu Criador e Remidor". Assim, prosseguia o autor, se "era senhor do caminho e da conquista, também lhe convinha o senhorio do comércio dela", para os "quais títulos não houve mister mais escritura que a primeira doação apostólica" e, quanto à navegação, "foi sempre tão grande a potência de nossas armadas naquelas partes orientais, que por sermos com elas senhores dos seus mares, quem quer navegar, ora seja gentio, ora mouro, para segura e pacificamente o poder fazer, pede um salvo conduto aos nossos capitães" - os chamados "cartazes" - direito estendido também aos povos cristãos, afinal "antes de nossa entrada na Índia, com a qual tomamos posse dela, não havia algum que lá tivesse propriedade" (BARROS, 1973 [1552], p. 15-16).

João de Barros apresentava assim todos os termos da questão. A prioridade da navegação justificava as leis e ordens régias, como aquelas incorporadas nas Ordenações do Reino, que vedavam o acesso aos estrangeiros aos mares agora conhecidos, as concessões do papado legitimavam a conquista, em nome da expansão da fé, mas era o poder das armadas, em última instância, que poderia manter os mares "fechados" sob controle da Coroa. O domínio efetivo sobre apenas uma ínfima porção das terras "descobertas" exigia, dada a ambição do monopólio do comércio, o controle do mar, pois seria a única forma de impedir o comércio das demais nações europeias com os povos dos demais continentes.

Essa foi a doutrina que justificou a repressão feroz aos intrusos - especialmente franceses, ingleses e holandeses - na África, na Ásia e na América. Tal doutrina, porém, só podia durar enquanto Portugal pudesse manter a hegemonia naval e militar no ultramar, porquanto só à força poderia manter o mar fechado às demais potências europeias.

Neste sentido, pode-se dizer que a obra do frei Serafim de Freitas, Do justo império asiático dos portugueses, ${ }^{29}$ de 1625, máxima expressão da defesa da doutrina, foi escrita no mesmo momento em que esta já estava sendo destruída na prática no seu último reduto, os mares orientais.

No caso do Brasil, foi o fracasso em impedir o acesso, especialmente dos franceses, ao território que incentivou o processo efetivo de colonização, com a doação das chamadas capitanias hereditárias na década de $1530 .{ }^{30}$ A situação é singularmente apresentada por Diogo de Gouveia. O humanista e teólogo, radicado na França, em conselho ao rei D. João III, explicava "quando lá (nas terras do Brasil) houver sete ou oito povoações, estas serão bastante para defenderem (impedirem) aos da terra que não vendam (pau) brasil a ninguém 
e não o vendendo as naus (francesas) não hão de querer lá ir para virem de vazio". 31

Assim, no Brasil, a partir da década de 1530, a luta pelo controle do mar seria substituída pela tentativa de controlar a terra, particularmente a fachada oceânica do território, vedando o acesso direto aos gêneros da terra. Dessa forma, com a fundação das primeiras capitanias, abrir-se-ia uma situação dual: mantinha-se o combate aos estrangeiros que questionassem o domínio português, mas permitia-se o comércio legal das áreas recém- ocupadas com o estrangeiro, 32 inclusive com a presença de mercadores não portugueses nos portos americanos durante o século XVI. ${ }^{33}$ Situação atestada, por exemplo, por Domingos de Abreu e Brito, que, após passar por Pernambuco durante viagem a serviço da Coroa em Angola em 1591, descrevia assim o movimento no porto: "mormente haver tantos navios", na capitania de Pernambuco, "de todas as partes, de França, Flandres, Inglaterra, Hamburgo e de todas as mais partes, assim das partes de que V. M. tem recebido desserviços, como dos mais, que será dificultoso serem vedados" (BRITO, 1933 [1592], p. 73).

Convém lembrar que o comércio de produtos de Portugal, notadamente o sal, bem como o interesse despertado pelos negócios ligados à expansão ultramarina dinamizaram uma série de relações comerciais entre Portugal e as demais regiões da Europa, além de favorecer a instalação nos principais portos portugueses de mercadores estrangeiros, mais ou menos radicados no país.

Em relação ao Brasil, no século XVI, pode-se dizer que os grupos mercantis estrangeiros não se limitaram ao papel de compradores e redistribuidores dos produtos coloniais na Europa, tendo também participado, em menor medida, no financiamento da montagem da indústria açucareira ${ }^{34}$ e, em maior medida, no comércio e transporte de produtos entre a Europa e o Brasil. ${ }^{35}$

A respeito destas últimas atividades, várias eram as formas de atuação. Comércio direto, legal ou não, entre o Brasil e seus países de origem ou comércio via Portugal; com mercadorias estrangeiras e/ou portuguesas; em associação ou não com mercadores de Portugal ou ainda associados a mercadores cristãos-novos portugueses radicados no exterior; ou simplesmente fretando navios para mercadores portugueses ou para a Coroa de Portugal.

Ainda que a documentação seja escassa, é possível perceber a presença estrangeira no comércio e no transporte entre o Brasil e a Europa. Atraídos pela prosperidade da economia colonial, aproveitando-se dos laços mercantis anteriormente estabelecidos em Portugal e possivelmente também da incapacidade da marinha portuguesa em escoar a totalidade da produção, a participação dos estrangeiros, especialmente holandeses e alemães, ${ }^{36}$ ganhou notável destaque no final do século XVI, sobretudo após 1580. Paradoxalmente, durante os primeiros anos da União Ibérica, a ação da pirataria dos inimigos da Coroa espanhola, ${ }^{37}$ ao desarticular a navegação portuguesa com a captura de inúmeras caravelas, teria contribuído para a maior participação dos barcos estrangeiros, em parte destes mesmos inimigos, o que, por sua vez, teria contribuído para a decisão régia do fechamento do 
acesso estrangeiro aos portos do Brasil. ${ }^{38}$

Vejamos então com mais detalhe esse processo. Pelos forais das chamadas capitanias hereditárias era lícito o comércio direto do Brasil com outros reinos. O Foral da Capitania de Pernambuco, que serviria de modelo aos demais, regulamentava assim o comércio: "Todos os navios de meus reinos e senhorios que à dita terra forem com mercadorias de que já cá tenham pagos os direitos ... não pagarão na dita terra do Brasil direito algum e se lá carregarem mercadorias da terra pera fora do Reino pagarão de saída dízima a mim". Contudo, no caso de embarque para o Reino se isentava o pagamento da referida dízima (procedimento, diga-se de passagem, que daria margem a uma série de fraudes). Na sequência, o documento é ainda mais esclarecedor: "quaisquer pessoas estrangeiras que não forem naturais de meus reinos ou senhorios que a dita terra levarem ou mandarem levar quaisquer mercadorias", mesmo que a partir de Portugal e com a dízima já paga, "pagarão lá de entrada dízima a mim das mercadorias que assim levarem e carregando na dita capitania mercadorias da terra para fora pagar-me-hão assim mesmo dízima da saída". ${ }^{39}$

Tal situação de liberdade do comércio não seria alterada com a criação do Governo-Geral, ${ }^{40}$ mantendo-se o quadro de isenções fiscais e de incentivos ao desenvolvimento do território e em especial da produção açucareira.

Ainda que não conste de nenhuma das citadas coleções de leis sobre o comércio enviadas ao Brasil, parece-nos pertinente tratar da "Lei de como hão de ir armados os navios que destes reinos navegarem" promulgada por D. Sebastião em 3 de novembro de $1571 .^{41}$ Tal lei não vedava o comércio estrangeiro no Brasil, apenas dava preferência aos navios portugueses, bem como elencava uma série de medidas para a segurança e defesa dos navios. ${ }^{42}$

Com o grande desenvolvimento da produção, o tom das disposições régias começa a mudar, ainda que mantenha a política de incentivo. A Coroa começava a tentar coibir as fraudes fiscais, que se aproveitavam das brechas abertas na legislação, em especial, a da isenção de pagamentos dados aos novos engenhos e aos proprietários que enviassem o próprio açúcar para o Reino, bem como a da citada diferença no pagamento dos direitos alfandegários (no caso do envio das mercadorias para o Reino, que gozaria de isenção, ou para fora dele, pagando a dízima), quando se declarava que o navio iria para Portugal, mas na verdade acabava indo para fora. ${ }^{43}$

Tal mudança não alteraria, contudo, a possibilidade do comércio direto do Brasil com outros reinos. Fato atestado, por exemplo, na seguinte passagem do regimento de 1577 , que versava sobre a arrecadação dos tributos e que orientava os oficiais régios sobre os procedimentos a serem tomados nas alfândegas: "quando algumas pessoas vierem a despachar seus açúcares [...] sendo pera fora do reino tho despacharão pagando o direito que 
devem". ${ }^{44}$

Seria só após o início da chamada União Ibérica que o quadro se alteraria e o comércio direto com os reinos estrangeiros seria de fato proibido, fruto, em nosso entendimento, muito mais da rivalidade política e dos conflitos militares (e religiosos) da Monarquia de Filipe II da Espanha (I de Portugal) com a Holanda, Inglaterra e França, ${ }^{45}$ então estendidos para Portugal, do que de uma política puramente econômica, ainda que argumentos mercantilistas também fossem utilizados, como veremos adiante no preâmbulo do Alvará de 9 de fevereiro de $1591{ }^{46}$ Esta sim é a primeira lei que proibiu o comércio com o estrangeiro no Brasil, fato corretamente apontado por D. Fernando José de Portugal.

Nessa conjuntura, o mecanismo de proibição do comércio, visando enfraquecer os inimigos, já tinha sido lançado mão pela Espanha. Assim, em 29 de maio de 1585, Felipe II de Espanha decretou a apreensão dos navios holandeses, ingleses e alemães nos portos da Península lbérica, ${ }^{47}$ interrompendo o comércio, ainda que provisoriamente, com tais países e apoderando-se de considerável número de embarcações. ${ }^{48}$ Neste sentido, a extensão da proibição do comércio com as áreas ultramarinas portuguesas em 1591, como dissemos, poderia ser entendida muito mais como uma ação contra os inimigos da Coroa espanhola do que como a implementação de uma nova doutrina que norteasse a relação entre a metrópole e suas colônias, estabelecendo assim o que depois se convencionou chamar de Antigo Sistema Colonial.

A promulgação da proibição do comércio direto entre o Brasil e o estrangeiro, fosse conduzido por portugueses ou por estrangeiros, teria sido gestada na segunda metade da década de 1580, não sem alguma confusão, visível na documentação do período.

Neste sentido, a carta escrita em 1587 por João de Teive, Contador-mor do Reino, ${ }^{49}$ para personagem desconhecido, na qual respondia a uma solicitação do monarca, nos dá algumas pistas sobre os possíveis antecedentes do Alvará de 1591.50

João de Teive declarava, em primeiro lugar, que "provisão particular que defenda [proibir] a naus flamengas, francesas e inglesas irem às partes do Brasil, nesta casa não há" e indicava que "pode ser que no foral que se deu as ditas partes haja particular capítulo que trate desta matéria [...] o que nela [matéria] sei dizer que por uso antiquíssimo se não permite tal comércio", pelo dano causado à Fazenda Régia pelos direitos não pagos. Como se viu, os forais das capitanias, de fato, tratavam do assunto, mas, ao contrário da opinião de João de Teive, permitiam tal comércio, daí como explicar o tal "por uso antiquíssimo" que o proibiria? Possivelmente, também nesse caso, o autor, confundindo-se, estendia as antigas proibições que tentavam vedar as novas rotas oceânicas aos estrangeiros para a realidade do Brasil pós-fundação das primeiras capitanias.

Na sequência da carta ele explicava os grandes prejuízos para a Fazenda Real nos direitos dos açucares e algodões, pois em Portugal estes produtos pagavam vinte por cento e "posto que os ditos açúcares paguem dez por cento por saída no Brasil quando se de lá 
direitamente levam pera fora do Reino" (atestando a permissão), na prática, seriam, em sua avaliação, apenas quatro por cento, em virtude do modo como eram despachados, tanto no que tocava ao peso, como na avaliação, causando evidente prejuízo.

Explicava ainda que "costumando os naturais levar das ditas partes do Brasil açúcares para fora do Reino", uma provisão "em tal modo se lhes limitou esta liberdade que quase Ihe é impossivel fazer a dita navegação para que desta maneira viesse tudo a este reino", arrematando na sequência: "tudo isso tenho dito sobre a intenção que os reis passados tiveram de trazer a este reino todas as mercadorias do Brasil fechá-lo com uma chave" como se poderia ver na provisão que teria limitado essa possibilidade.

Infelizmente, até agora não foi possível localizar a citada provisão para averiguarmos quais seriam os termos de tais limitações, mas o próprio João de Teive, ao explicar que a "provisão de limitação que acima aponto e de todos os mais regimentos tocantes aos naturais, porque em estrangeiros que as ditas partes fossem comerciar não falam", nos dá uma indicação de outra possivel confusão. ${ }^{51}$

Consequentemente, João de Teive explicava, "se houve por crime grave ir à nau inglesa ás ditas partes do Brasil no ano de oitenta e quatro [1584], de que se a terra espantou por novidade e muito mais de passar sem castigo" e, por fim, o autor apontava que ainda mais grave era o caso "presente da urca de Gelanda [Zelândia, província da Holanda], de inimigos de Sua Majestade, que não podem ter comércio em seus estados".

Enfim, como entender tal carta? O comércio direto com o estrangeiro já teria sido limitado ou proibido, conforme a intenção dos reis precedentes? Qual seria o problema ligado à presença da nau inglesa nas partes do Brasil? Tais dúvidas nos parecem causadas por uma confusão entre quais seriam as condições do comércio com estrangeiros então vigentes, as fraudes destas condições e as relações e conflitos com súditos de uma monarquia rival (Inglaterra) e com vassalos de uma província "rebelde" (Holanda).

O regimento do provedor-mor da Fazenda do Brasil, Baltazar Rodrigues de Sousa, de 1588, nos ajuda a entender os problemas levantados pela carta de João de Teive. Um dos itens do regimento deixa claro que o comércio ainda era livre:

[...] pelos livros das ditas alfândegas vereis em que forma se arrecadam os direitos e se se guarda ordem e verdade nas avaliações das mercadorias que vão de fora do reino, que por obrigação hão de pagar dízima por entrada e a forma e vigia que se tem nos navios que carregam naquelas partes açúcares para fora do reino, e como se faz a avaliação deles para a dízima que hão de pagar por saída a minha fazenda. ${ }^{52}$

O provedor-mor ainda deveria ver em cada uma das capitanias os "livros das saídas dos navios que despacham para este reino e vereis as fianças que são dadas nos mesmos livros e das que achardes desobrigadas pedireis certidões [...]", evidentemente para coibir as fraudes já apontadas. 
Por fim, o regimento esclarece o episódio da nau inglesa: "sou informado que a capitania de Pernambuco foi ter uma nau inglesa [...] com muitas fazendas, cujos direitos importavam sete ou oito mil cruzados, que se não carregaram em receita nos livros daquela alfândega". Assim, o problema não seria o trato comercial, mas a fraude possivelmente praticada pelos oficiais da Alfândega.

Por outro lado, apenas quatro dias antes, no regimento dado ao novo governador- geral, Francisco Giraldes, o Rei, após informá-lo sobre a presença de naus estrangeiras no Brasil, levando mercadorias e retornando com açúcares, o que seria "muito inconveniente para a segurança", citando, como exemplo, o caso de uma urca estrangeira que se teria passado para o lado dos corsários ingleses, ${ }^{53}$ mandava então "que daqui em diante não se consinta nos portos de toda a costa das ditas partes naus algumas estrangeiras", exceto com licença do próprio monarca. ${ }^{54}$

Tal medida, contudo, não seria posta em vigor, dado o fracasso da viagem de Francisco Giraldes, que acabaria retornando ao reino sem conseguir desembarcar no Brasil. Interessante, porém, é percebermos o desenvolvimento do processo. Assim, se as naus estrangeiras, salvo com licença régia, seriam proibidas por questões de segurança nos portos do Brasil nas ordens dadas ao governador-geral, a permissão do comércio com o estrangeiro, como vimos, permanecia nas disposições dadas ao provedor-mor. ${ }^{55}$

Isso seria corroborado pelo provimento de Lopo Fernandes para o cargo de guarda-mor do mar do Rio de Janeiro, passado em Salvador em 1589 pelos membros do Governo-Geral interino, que justificavam assim a nomeação: "por razão do concurso dos navios que a ela [capitania do Rio de Janeiro] vem do Peru, com prata, e ouro, e outras mercadorias e que despachavam para fora do reino, devendo direitos à Fazenda Real" ${ }^{56}$

Possivelmente, em decorrência do agravamento do conflito com as potências rivais, e aproveitando-se da ida de um novo governador-geral, D. Francisco de Sousa, a Coroa enfim tomaria a decisão de proibir todo o comércio com o estrangeiro no final de 1590 , ainda que o alvará seja assinado só em fevereiro de 1591.

No regimento dado a D. Francisco de Sousa em dezembro de 1590, o monarca encarregava o governador-geral de colocar em prática a sua decisão, que então já era conhecida, ou pressentida, entre os servidores da Coroa e talvez também nos círculos mercantis, ${ }^{57}$ como se percebe pelo relato, de dezembro de 1590, da reunião de uma junta, realizada em Lisboa, para avaliar a proposta que Martim Carvalho ${ }^{58}$ apresentou sobre uma nova forma de cobrança dos dízimos. Tal proposta permitiria um aumento da arrecadação do dízimo, além do rendimento das alfândegas que, contudo, segundo relato da reunião, "será pouco havendo efeito a proibição do comércio dos estrangeiros no Brasil e a navegação do açúcar para fora do Reino e que com esta conta ser tão fundada em razão não há lance nestes dízimos", atestando assim a importância da mudança que o alvará de 1591 introduziria pouco tempo depois. ${ }^{59}$ 
Vejamos agora com mais detalhes o Alvará de 9 de fevereiro de $1591 .{ }^{60}$ Filipe II da Espanha apontava, como justificativa para a decisão, o estado do tempo presente "em que a Igreja Católica está tão perseguida e oprimida de heresias semeadas pela maior parte da cristandade de que resulta sua comunicação e comércio de estrangeiros nas ditas conquistas de muito perigo para conservação da pureza da fé" principalmente "na nova cristandade", além do dano que recebe o reino com tal comércio, como a "experiência tem mostrado da devassidão que de alguns tempos a esta parte em este modo de navegação, de que procede ir faltando o grande trato e comércio que sempre teve este Reino por causa das mercadorias das ditas conquistas que a ele vinham buscar as nações estrangeiras que delas careciam", fato que contrariaria a razão e o bom governo, pois "sendo os lugares das ditas conquistas descobertos e povoados a custa do patrimônio Real desta Coroa e com os serviços e merecimentos dos vassalos dela para geral proveito e utilidade e crescimento de minhas rendas, as quais tem recebido muita perca".

O remédio, portanto, para tal situação, ainda segundo o Alvará de 1591, seria a proibição de navios estrangeiros de "qualquer sorte e qualidade que seja, possa ir nem vá dos portos deste Reino, nem de fora deles às conquistas do Brasil", bem como para as áreas africanas sob domínio português; a proibição do fretamento de naus estrangeiras, nem levar em navios "naturais" marinheiros, mercadores ou passageiros estrangeiros e, por fim, que "não possam partir para as ditas conquistas, se não dos lugares e portos deste Reino [...] e serão obrigados a tornar das ditas conquistas diretamente aos portos do dito Reino", salvo, em todos os casos, se munidos de "particular licença" da Coroa, com severas penas aos transgressores. ${ }^{61}$ Dessa forma, estabelecia-se, pelo menos juridicamente, o que mais tarde viria a ser conhecido como "exclusivo metropolitano".

Contudo, as dificuldades de impor tal medida eram evidentes, pois, como relatava Domingos de Abreu e Brito, o Brasil era "muito frequentado de naus estrangeiras pelo interesse e proveito que recebem de converterem suas mercadorias em açúcares", além de "suas fazendas serem tão necessárias em as ditas capitanias" e de forma que tal comércio "tanto importa ao interesse dos estrangeiros, como [dos] portugueses".

Dessa forma, para impedir "todos os navios estrangeiros, não bastara o poder do mundo a lhe estorvar o comércio nas tais capitanias, que carregam para este reino e se fazem vela" para outros países. Conselho que reforçaria, sintetizando a questão: como vem "muitos navios de deservidores [sic] de V. M. ... será trabalho ser thes vedado [o comércio] [...] pelo proveito que tem na venda de suas fazendas, [...] [e] pelo trato dos açúcares de que os moradores recebem tantos proveitos" (BRITO, 1993 [1592], p. 66, 74, 80, 86).

Domingos de Abreu e Brito, na obra de 1592, que relatava as suas observações feitas entre 1590 e 1591 em Angola e no Brasil, não fez menção explícita à proibição do comércio de 1591, e, ao contrário, sugeriu apenas novas medidas fiscais para evitar as fraudes contra a Fazenda Real e ampliar os ganhos das alfândegas. Em seus conselhos, contudo, o autor apontava o cerne da questão: os interesses mútuos que incentivavam tal comércio. 
Além disso, não se pode esquecer a enorme prosperidade das áreas açucareiras do Brasil no final do século XVI e começo do XVII. A vitória sobre a resistência indígena no litoral abriu caminho para a apropriação de terras e escravos. Os incentivos fiscais, a baixa tributação, a demanda europeia e os preços favoráveis completam um quadro extremamente favorável para os grandes proprietários e para os grupos mercantis envolvidos no comércio entre o Brasil e a Europa. ${ }^{62}$

Os relatos de Gabriel Soares de Sousa, do jesuíta Fernão Cardim e do francês Pyrard de Laval comprovam largamente a incrivel prosperidade vista por Domingos de Abreu e Brito entre 1590 e 1591. Outro exemplo que ajuda a entender o tamanho dos ganhos mercantis naquele momento e, portanto, da atração que o Brasil exercia entre os mercadores é uma passagem dos Diálogos das Grandezas do Brasil, de 1618.

Alviano, personagem que representa o recém-chegado à terra, questiona: "[...] mas toda essa mercancia de que tendes tratado, de que se tira tanto proveito, parece que se vem a resumir em mãos de estrangeiros, ${ }^{63}$ e dos tais é o proveito, e não dos naturais da terra". Brandônio, o morador experiente, responde então que os naturais da terra raramente se envolvem no comércio, salvo um ou outro que mandam os próprios açúcares para o reino, preferindo a maioria apenas tratar dos engenhos e lavouras, "deixando no demais a porta aberta aos mercadores". Para arrematar, conta o caso de um mercador "de pouco porte" que, em 1592, chegou em uma caravela a Pernambuco. Trazendo vinhos, azeite, passa e figos, dentre outras coisas, após seis meses na terra teria quase quadruplicado o valor dos produtos trazidos, investindo em açúcar branco, "pela barateza que os comprou, devia de dobrar outra vez o dinheiro no reino". Alviano, então sentenciava: "terra donde tanto proveito tiram os que nela negociam, confesso que não pode deixar de ser muito rica" (DIÁLOGO, 1962, p. 96-97).

Independente da exatidão dos números de Brandônio, a lucratividade - real e também esperada - do comércio com o Brasil era um atrativo que incentivava os maiores riscos e, evidentemente, dificultava ainda mais a tentativa de a Coroa impedir o comércio estrangeiro. ${ }^{64}$

A própria Coroa em 1605 reconheceria o insucesso das medidas tomadas no alvará de 1591. O maior problema aludido, neste que seria o segundo alvará repressivo, eram as licenças concedidas aos navios estrangeiros, vista a incapacidade da marinha portuguesa em responder às necessidades do tráfico.

Em uma espécie de círculo vicioso, naquele momento de grande crescimento da produção açucareira, os inimigos da Coroa Espanhola enfraqueciam a capacidade da Marinha portuguesa com ações de pirataria, obrigando assim a uma ainda maior utilização de barcos estrangeiros, ao mesmo tempo que se tentava fechar o comércio do Brasil aos estrangeiros. Essa situação pode ser simbolicamente retratada na própria viagem de D. Francisco de Sousa, pois uma provisão régia concedia licença para carregar açúcar no Brasil às duas urcas estrangeiras fretadas para a viagem do governador-geral, encarregado de executar 
O alvará de $1591 .^{65}$

Dessa forma, a prática da concessão de licenças abria a porta para uma série de fraudes. Nos termos do alvará de 1591, descritos no de 1605, as licenças seriam dadas aos navios para "partirem do reino de Portugal em direitura para as partes declaradas [...] e tornarem em direitura a Portugal" e que tais navios "seriam de nações amigas e não das rebeldes e outros inimigos". Na prática, porém, tais licenças "se tem usado mal, mandando com provas falsas, alguns navios de rebeldes, e derrotando-se à torna viagem para fora" de Portugal "contra o que tinham prometido, e sem embargo das fianças que tinham dado" por culpa dos contratadores e de "vassalos meus, que por seus interesses e respeitos particulares, faziam derrotar os ditos navios e cometiam outros enganos e fraudes". ${ }^{6} 6$

Decorrência disso eram perdas para a Fazenda Real e perda do comércio do reino com a saída para "terras e reinos estranhos as mercadorias e fazendas que se trazem de meus estados Ultramarinos e faltarem em Portugal", desestimulando a construção naval e a formação de marinheiros, que depois poderiam servir nas armadas reais.

A resposta encontrada pela Coroa em 1605 foi endurecer os termos. Assim, o rei mandava que "não possa navio algum de quaisquer nações estrangeiras" ir aos domínios ultramarinos, revogando todas as licenças concedidas e estabelecendo as costumadas medidas punitivas (MENDONÇA, 1960, p. 86).

Evidentemente, as novas disposições régias não foram fielmente aplicadas, a própria Coroa seria obrigada a conceder novas licenças, ${ }^{67}$ e o comércio clandestino, articulando interesses portugueses e estrangeiros, também continuou. ${ }^{68}$ Mas o fato é que as disposições do alvará de 1591, reforçadas em 1605, foram estabelecendo uma nova situação, registrada na documentação de cunho oficial do período. Os inúmeros relatos de casos de fraudes e contrabando realizados, de tentativas projetadas ou fracassadas de burlar as novas regras, de apreensões de navios e mercadorias e, inclusive, de um possível caso de resistência armada contra as ordens da Coroa, demonstram a disposição de impor as novas regras e a dificuldade cada vez maior para burlá-las. ${ }^{69}$

Testemunho importante desta situação é o relato dado por frei Vicente do Salvador sobre o caso de uma urca flamenga no Espírito Santo durante o governo de Diogo Botelho, entre 1602 e 1608. Escrevendo vinte anos depois do episódio, frei Vicente explicitava as mudanças ocorridas naquele momento: "costumavam vir ao Brasil urcas flamengas despachadas e fretadas em Lisboa, Porto e Viana, com fazendas da sua terra e de mercadores portugueses para levarem açúcar"70 e tendo ido uma destas embarcações ao Espírito Santo, acertou-se lá com o capitão e com jesuítas, que em troca de uma carga de pau-brasil, que buscariam no ano seguinte, trariam ornamentos para a Igreja. O retorno, contudo, ocorreu depois do alvará de 1605; o negócio acordado não foi realizado e, ainda segundo o relato de frei Vicente do Salvador, depois de entrar em choque com as forças enviadas por Martim de Sá, governador do Rio de Janeiro, o barco acabou naufragando e parte da tripulação presa. 
Contudo, bem mais interessante do que o relato das desventuras da nau flamenga é a explicação dada às disposições do alvará de 1605. O Rei, "informado que por essas urcas serem mais fortes e artilhadas, todos queriam carregar nelas e cessava a navegação dos navios portugueses e quando os quisesse para armadas não os teria, nem soubesse a arte de navegar", escreveu ao "governador Diogo Botelho e aos mais capitães não consentissem mais em suas capitanias entrar navio algum de estrangeiros por via de mercancia nem por outra alguma, mas os metessem no fundo e perseguissem como a inimigos" (SALVADOR, 2008 [1627], fl.149).

Outro episódio, curioso e de difícil esclarecimento, mas emblemático da situação, é o caso de um tal Sebastião da Rocha. Em uma versão, teria "com negros flecheiros e alguns portugueses" impedido a ação dos soldados enviados para capturar um navio inglês no litoral de Pernambuco e, em outra, ao contrário, teria capturado o mesmo navio, mas se apoderado das mercadorias trazidas. Possivelmente envolvido no contrabando, sendo descoberto, teria traído os ingleses, mas denunciados por estes, acabou preso. ${ }^{71}$

Por fim, um último relato, da perspectiva de um holandês. O piloto Henrich Ottssen conta as aventuras de seu navio, que, saindo da Holanda, teria ido até a Guiné, depois cruzado o oceano até o Rio da Prata e, finalmente, após a morte de grande parte da tripulação, foi capturado na Bahia, onde tencionava buscar ajuda de navios alemães, pouco antes do primeiro grande ataque holandês a Salvador em 1599.72

A primeira situação que nos interessa destacar é a tentativa de comércio em Buenos Aires, evidentemente contrária às leis espanholas. Ottssen descreve as tratativas com o governador local, as pressões favoráveis dos moradores e o desenlace das negociações, com a prisão de parte dos marinheiros e a impossibilidade do negócio. ${ }^{73} \mathrm{~A}$ segunda é a tensão, descrita ao longo do livro, de serem capturados, especialmente pelos portugueses, com o "perigo de perder nestas costas, não só o barco e as mercadorias, mas as próprias pessoas, caindo sacrificados ou em um duro e largo cativeiro" (OTTSSEN, 1945 [1603], p. 71).

O livro de Ottssen, editado na Holanda em 1603 e 1617, traduzido para o alemão em 1604 pela famosa casa De Bry e filhos, não era, evidentemente, um incentivo à ação de mercadores estrangeiros no Brasil, demonstrando claramente os riscos do comércio ilegal.

A participação estrangeira na atividade açucareira, como vimos, teve várias facetas, mas, em geral, esteve associada a mercadores portugueses. Ela foi essencial na redistribuição do açúcar na Europa; fundamental no transporte entre os dois lados do oceano nas últimas duas décadas do século XVI e nos primeiros anos do XVII; importante no comércio direto nas áreas produtoras do Brasil $^{74}$ e secundária no financiamento dos engenhos. ${ }^{75}$

Tanto a associação comercial com estrangeiros nas várias fases do negócio, como a 
participação destes na navegação e comércio, mediante licenças, desde que cumpridas as regras que exigiam a navegação direta, na ida e na volta, entre Portugal e o Brasil, não implicam a negação do exclusivo metropolitano. Significam apenas que Portugal, por incapacidade econômica ou por necessidade político-diplomática, cedia parte dos ganhos coloniais para tais parceiros. ${ }^{76}$

O contrabando, dentro de certos limites, também não altera a essência do sistema, pois significa também, embora por meios ilícitos, a transferência de parte dos ganhos para grupos mercantis estrangeiros e para seus respectivos países (NOVAIS, 1995, p. 91). ${ }^{77}$

O estabelecimento do exclusivo metropolitano não pressupõe, portanto, a necessidade que nenhum navio ou comerciante estrangeiro, por meios legais ou ilegais, participe do negócio, mas, sim, que, ao se restringir a concorrência, se criem as condições para que a venda de produtos europeus e a compra dos produtos coloniais sejam tendencialmente as mais favoráveis possíveis para os grupos mercantis metropolitanos. ${ }^{78}$

Tal situação, em termos práticos, era explicada pelo Conselho da Fazenda ao Rei, a partir de queixa dos mercadores portugueses contra uma licença dada a barcos genoveses para ir ao Brasil, pois "chegando com as ditas fazendas ao Brasil, assim por não haverem pago aqui direitos, como pelas levarem de primeira mão, as venderão mais baratas que as mandadas pelos portugueses, com o que estes ficarão perdidos" e, como consequência "ajuntasse a isto que achando-se no Brasil os genoveses, com o ganho e com dinheiro que também levam comprarão o açúcar por alto preço, com que o farão subir, estando ele já excessivamente alto" ${ }^{79}$

Dessa forma, o exclusivo metropolitano do comércio colonial, ou seja, a reserva do mercado das colônias para a metrópole é, nas palavras de Fernando Novais, "o mecanismo fundamental, gerador de lucros excedentes, lucros coloniais" (NOVAIS, 1995, p. 88).80

O resultado dessa situação era descrito por um observador anônimo no final do século XVIII. Para este, parte dos mercadores portugueses era

composta dos que fazem o forte do seu comércio com as nossas
colônias, o qual lhe assegura lucros avultados com pouco trabalho
pelos ricos gêneros que delas se extraem, pela pouca inteligência
e atividade, que requer um comércio, que os nossos negociantes
fazem sem sofrem concorrência de atividade e inteligência dos
negociantes estrangeiros [...]. ${ }^{81}$

desinteressando-se, consequentemente, do comércio com outras áreas. ${ }^{82}$

Retomando o processo histórico concreto, podemos dizer que o exclusivo metropolitano foi paulatinamente se impondo a partir dos alvarás de 1591 e 1605, ainda que o comércio com o estrangeiro, legal ou ilegal, nunca tenha sido completamente extinto. As disposições da Coroa, as ações de pirataria e os ataques à colônia praticados por ingleses, holandeses e franceses foram criando as condições para a imposição do exclusivo. A marcante presença estrangeira no comércio colonial entre 1580 e 1605 foi, a partir deste 
momento, regredindo até a década de 20 do século XVII. ${ }^{83}$ A conquista da Bahia (1624-25) e de Pernambuco (1630-1654) pelos holandeses simbolicamente indicariam o fim desse processo. ${ }^{84}$

Portanto, o estabelecimento do exclusivo metropolitano, ou seja, o fim do regime de livre comércio na colônia, deve ser entendido como um processo. Iniciado no final do século XVI, teria se consolidado durante a segunda década do XVII e concluído até a invasão de Pernambuco em 1630, sem que isso signifique, insistimos mais uma vez, que licenças, fraudes e contrabando tenham deixado de existir completamente. ${ }^{85}$

Paralelamente ao estabelecimento do exclusivo metropolitano, outro processo fundamental estava se desenvolvendo. A transição do trabalho indígena para o africano nas áreas centrais da economia açucareira. A economia açucareira erguida com a mão de obra indígena "barata", fruto da guerra de conquista, passava a suprir suas necessidades crescentes de trabalho com os mais "caros" escravos africanos. ${ }^{86}$

Dessa forma, no começo do século XVII, a cada vez maior dependência do tráfico africano e o estabelecimento do exclusivo metropolitano turvaram o "tempo dourado" dos senhores de engenho do final do século XVI (RICUPERO, 2012, p. 337).

Ao contrário do que pensava o Visconde de Cairu, o Sistema Colonial não foi firmado pelas potências europeias no Congresso de Utrecht. ${ }^{87} \mathrm{Na}$ verdade, o Sistema Colonial não foi decretado ou instituído por nenhuma lei, mas conformou-se, no caso do Brasil, a partir do estabelecimento do exclusivo metropolitano, reforçado pelo tráfico africano de escravos no começo do século XVII. Delineado por Fernando Novais, é, nas palavras de Luiz Felipe de Alencastro, o "processo de colonização dos colonos". ${ }^{88}$ A plena consciência sobre o fenômeno colonial, contudo, só surgiria tempos depois.

\section{Referências}

ALENCASTRO, Luiz Felipe de. O aprendizado da Colonização. In: O trato dos viventes. São Paulo: Companhia das Letras, 2000.

ALMEIDA, Candido Mendes (ed.). "Ordenações Filipinas (1603)", Código Philippino. Rio de Janeiro: Instituto Philomático, 1870.

ANTT - Arquivo Nacional da Torre do Tombo.

ARRUDA, J. J. de Andrade. Uma colônia entre dois impérios. Bauru: EDUSC, 2008.

ARRUDA, José Jobson de Andrade. O Brasil no comércio colonial. São Paulo: Ática, 1980.

ARRUDA, José Jobson de Andrade. Superlucros: a prova empírica do exclusivo colonial. 
Topoi. Rio de Janeiro, v. 15, n. 29, p. 706-718, jul.-dez. 2014.

BA - Biblioteca da Ajuda.

BARROS, João de. Da Ásia de João de Barros, dos feitos, que os portugueses fizeram no descobrimento e conquista dos mares e terras do Oriente. (1552) Lisboa: San Carlos, 1973. $8 \mathrm{v}$.

BERGER, Paulo; WINZ, Antonio Pimentel; GUEDES, Max Justo. Incursões de corsários e piratas na costa do Brasil. In: História Naval Brasileira. Rio de Janeiro: Ministério da Marinha, 1975. v. 1. t. II. p. 473-521.

BIKER, Julio. Suplemento à Colleção dos Tratados, Convenções, Contratos e Actos Públicos celebrados entre a Corôa de Portugal e as mais potências desde 1640 compilados, coordenados e annotados pelo Visconde de Borges de Castro. Lisboa: Imprensa Nacional, 1878. t. 15.

BRAUN, Carlos Rodríguez. La cuestión colonial y la economia clásica. Madrid: Alianza, 1989.

BRITO, Domingos de Abreu e. Sumário e descrição do Reino de Angola e do descobrimento da ilha de Luanda. (1592) In: FELNER, Alfredo de Albuquerque. Um inquérito à vida administrativa e econômica de Angola e do Brasil. Coimbra: Imprensa da Universidade, 1933. p. 3-97.

BROUGHAM, Henry. An Inquiry into the colonial policy of the european powers. Edinburg; London: D. Willison, Craig's Close, for E. Balfour, Manners \& Miller, and Archibald Constable; T. N. Longman \& O. Rees, 1803. 2v.

CAETANO, Marcelo. Introdução. In: FREITAS, Frei Serafim de. Do justo Império Asiático dos portugueses. Lisboa: Instituto de Alta Cultura, 1960. p. 7-61.

CAMARGO, Ana Maria; MORAES, Rubem Borba de. Bibliografia da Impressão Régia do Rio de Janeiro. São Paulo: EDUSP, 1993. v. 1.

CARDOSO, José Luis (ed.). Memórias Econômicas Inéditas (1780-1808). Lisboa: Academia das Ciências de Lisboa, 1987.

CARDOSO, José Luis; MONTEIRO, Nuno; SERRÃO, José Vicente. Portugal, Brasil e a Europa Napoleónica. Lisboa: ICS, 2010.

CASTRO, Armando. A dominação inglesa em Portugal. Porto: Afrontamento, 1974. 
CASTRO, Visconde de Borges de. Colleção dos Tratados, Convenções, Contratos e Actos Públicos celebrados entre a Corôa de Portugal e as mais potências desde 1640. Lisboa: Imprensa Nacional, 1856. t. 2.

CAVALCANTE, Paulo. Negócios de trapaça. São Paulo: Hucitec, 2006.

CARVALHO, Gomes de. D. João III e os francezes. Lisboa: Clássica, 1909.

CHORÃO, Maria José. Doações forais das capitanias do Brasil 1534-1536. Lisboa: Torre do Tombo, 1999.

CLARK, Peter (ed.). The European Crisis of the 1590s. London: George Allen \& Unwin, 1985.

CORDEIRO, J. P. Leite. O engenho de São Jorge dos Erasmos. São Paulo: s.n., 1945.

CORREIO BRAZILIENSE (1808-1822) [Ed. fac-similar]. São Paulo: Imprensa Oficial, 2001. $32 \mathrm{v}$.

CORTESÃO, Jaime. Pauliceae Lusitana Monumenta Histórica. Lisboa: Real Gabinete Português de Leitura do Rio de Janeiro, 1956. v. 1.

COSENTINO, Francisco. Governadores Gerais do Estado do Brasil. São Paulo: Annablume, 2009.

COSTA, Hipólito da. Correio Braziliense (1808-1822) [Ed. fac-similar]. São Paulo: Imprensa Oficial, 2001. v. 1.

COSTA, Leonor Freire. O transporte no Atlântico e a Companhia Geral do Comércio do Brasil (1580-1663). Lisboa: CNCDP, 2002.

D'EÇA, Almeida. Normas Econômicas na Colonização Portuguesa até 1808. Coimbra: Imprensa da Universidade, 1921.

DH - Documentos Históricos. Rio de Janeiro: Biblioteca Nacional. v. 13.

DHA - Documentos para a História do Açúcar. Rio de Janeiro: IAA, 1956. 3v.

DIÁLOGO das Grandezas do Brasil. (1618) Editado por José Antonio de Gonsalves de Mello. Recife: Imprensa Universitária, 1962.

EBERT, Christopher. Between Empires: Brazilian sugar in the Early Atlantic Economy 15501630. Leiden e Boston: Brill, 2008. 
ELLIOTT, J. H. La Europa Dividida. 2. ed. Madrid: Siglo XXI, 1976.

FERLINI, Vera. Terra, trabalho e poder. São Paulo: Brasiliense, 1988.

FISCHER. De Methuen a Pombal. Lisboa: Gradiva, 1984.

FRAGOSO, João. A formação da economia colonial no Rio de Janeiro e de sua primeira elite senhorial. In: FRAGOSO; BICALHO; GOUVÊIA. O Antigo Regime nos trópicos. Rio de Janeiro: Civilização Brasileira, 2001. p. 29-71.

FRANÇA, Jean Marcel Carvalho; HUE, Sheila. Piratas no Brasil. São Paulo: Globo, 2014.

FREITAS, Frei Serafim de. Do justo Império Asiático dos portugueses. (1625) Lisboa: Instituto de Alta Cultura, 1960. 2v.

FURTADO, Celso. Formação econômica do Brasil. 24. ed. São Paulo: Companhia Editora Nacional, 1991.

HECKSCHER, Eli. La época mercantilista. México: Fundo de Cultura Económica, 1943.

ISRAEL, Jonathan. Dutch primacy in world trade, 1585-1740. Oxford: Claredon, 1991.

JOHNSON, E. A. J. American economic thought in the seventeenth century. New York: Russel \& Russel, 1961.

KANTOR, Íris. A Academia Real de História Portuguesa e a defesa do patrimônio ultramarino. In: BICALHO, Maria Fernanda; FERLINI, Vera (org.). Modos de governar: ideias e práticas políticas no Império Português XVI-XIX. São Paulo: Alameda, 2005. p. 257-279.

KNORR, Klaus. British Colonial Theories (1570-1850). Toronto: University of Toronto Press, 1963.

LISBOA, Baltazar. Anais do Rio de Janeiro (1834). Rio de Janeiro: Leitura, s/d. v. 1.

LISBOA, José da Silva. Escritos Econômicos Escolhidos (1804-1820). Lisboa: Banco de Portugal, 1993. v. 2.

LISBOA, José da Silva. Memória dos benefícios políticos do governo de El-Rey Nosso Senhor D. João VI (1818). Rio de Janeiro: Arquivo Nacional, 1940.

LIVRO 1 do Governo do Brasil (Século XVII). Rio de Janeiro: Ministério das Relações Exteriores, 1958.

M. V. D. F. [Farbonnais]. Colonie. In: DIDEROT, Denis; D'ALEMBERT, Jean Le Rond. 
Encyclopédie ou dictionnaire raisonné des sciences, des arts et des métiers. Paris: André le Breton, Michel-Antoine David, Laurent Durand, Claude Briasson, 1753. p. 648-651.

MALES QUE TEM RESULTADO a Portugal dos tratados de comércio com a Inglaterra. Lisboa: Lisbonense, 1840.

MARX, Karl. O Capital. (1867) Rio de Janeiro: Bertrand Brasil, 1989. L. 1., v. 2.

MAURO, Frédéric. Le Brésil au XVIIe siècle. Coimbra: Imprensa da Universidade, 1963. [Separata da Revista Brasilia, v. 11].

MELLO, José Antonio Gonsalves de. Diálogos das Grandezas do Brasil (1618). Recife: Imprensa Universitária, 1962 [1aㅡ edição integral].

MELLO, José Antônio Gonsalves de. Os Livros das Saídas das Urcas do porto do Recife, 1595-1605. Revista do Instituto Arqueológico, Histórico e Geográfico de Pernambuco, Recife, IAHGP, v. 58, p. 21-144, 1967.

MEMÓRIAS ECONÔMICAS INÉDITAS (1780-1808). Lisboa: Academia das Ciências de Lisboa, 1987.

MENDONÇA, Marcos Carneiro de. O Marquês de Pombal e o Brasil. São Paulo:

Companhia Editora Nacional, 1960.

MENDONÇA, Marcos Carneiro de. Raízes da formação administrativa do Brasil. Rio de Janeiro: IHGB e CFC, 1972. v. 2.

MIMS, Stewart. Colbert's West India Policy. New York: Octagon, 1977.

MIRAFLORES, Marquês de; SALVA, D. Miguel. Colección de Documentos Inéditos para la História de España. Madrid: Viuda de Calero, 1867. t. 51.

MONTEIRO, Rodrigo Bentes. Família, soberania e monarquia na República de Jean Bodin. In: BICALHO, Maria Fernanda; FERLINI, Vera (org.). Modos de governar. São Paulo: Alameda, 2005. p. 221-238.

NOVAIS, Fernando. Portugal e Brasil na crise do Antigo Sistema Colonial (1777-1808). 6. ed. São Paulo: Hucitec, 1995.

OLIVEIRA LIMA. Dom João VI no Brasil. 2. ed. Rio de Janeiro: José Olympio, 1945. v. 1.

OLIVEIRA, Luís Valente de; RICUPERO, Rubens. A Abertura dos Portos. São Paulo: SENAC, 2007. 
ORDENAÇÕES MANUELINAS. (1521) Lisboa: Fundação Calouste Gulbenkian, 1984. v. 5.

OTTSSEN, Henrich. Corto y verídico relato de la desgraciada navegación de un buque de Amsterdam... (1603) Tradução espanhola publicada no livro Un buque holandés en América Del Sur, 1598-1601. Buenos Aires: Huarpes, 1945.

PEDREIRA, Jorge. A economia política colonial In: FRAGOSO, João; BICALHO, Maria de Fátima (org.). O Brasil Colonial, 1720-1821. Rio de Janeiro: Civilização Brasileira, 2014. p. 419-460.

PINTO DE AGUIAR. A Abertura dos Portos, Cairu e os ingleses. Salvador: Progresso, 1960.

PORTUGAL E O SÉCULO XVI, Leis sobre a navegação e possessões do Império, Lisboa 1570-1573. Lisboa: Agência Geral das Colónias, 1943.

PRADO JR., Antônio (ed). Ordens e Provizoens Reays (Século XVII). Rio de Janeiro: Jornal do Brasil, 1928. v. 3.

PUNTONI, Pedro. Os holandeses no comércio colonial e a conquista do Brasil, 15401635. In: SZMRECSÁNYI, Tamás (org.). História Econômica do Período Colonial. São Paulo: ABPHE, Hucitec, 1996. p. 239-267.

RAU, Virgínia. Estudos sobre a história do sal português. Lisboa: Presença, 1984.

RAU, Virgínia. Um grande mercador-banqueiro italiano em Portugal: Lucas Giraldi. In: Estudos de História. Porto: Verbo, 1968. p. 75-129.

RAYNAL, Guillaume-Thomas. Histoire philosophique et politique des établissements et du commerce de européens dans les deux Indes. Genebra: Jean-Leonard Pellet, 1780. 9 v.

REIS, Arthur Cézar Ferreira. O comércio colonial e as companhias privilegiadas. In: HOLANDA, Sérgio Buarque de. História Geral da Civilização Brasileira. Rio de Janeiro, São Paulo: Difel, 1960. v. 2.

RIHGB - Revista do Instituto Histórico e Geográfico Brasileiro. Rio de Janeiro: IHGB, t. 62, $67,73,1906$.

RIBEIRO, João Pedro. Índice chronologico remissivo da legislação portugueza posterior a publicação do Código Filippino. Lisboa: Academia Real das Sciencias, 1826. Parte 5.

RICUPERO, Rodrigo. Formação da elite colonial. São Paulo: Alameda, 2008.

RICUPERO, Rodrigo. O tempo dourado do Brasil no final do século XVI. In: GARRIDO, 
Álvaro; COSTA, Leonor Freire; DUARTE, Luís Miguel (orgs.). Economia, Instituições e Império: estudos em homenagem a Joaquim Romero de Magalhães. Coimbra: Almedina, 2012. p. 337-348.

ROCHA, Antonio Penalves (org.). José da Silva Lisboa, Visconde de Cairu. São Paulo: Editora 34, 2001.

RODRIGUEZ-SALGADO, M. J.; ADAMS, Simon (orgs.). England, Spain and the Gran Armada 1585-1604. Edinburgh: John Donald, 1991.

SALVADOR, Frei Vicente do. História do Brazil. (1627) Edição crítica de Maria Lêda Oliveira. Rio de Janeiro: Versal, 2008.

SAVARY, Jaques. Dictionnaire Universel de Commerce [Ed. Fac-smilar]. Paris: Gallica, ed. de 1723.

SCHWARTZ, Stuart. Segredos internos. São Paulo: Companhia das Letras, 1995.

SERRATH, Pablo Oller Mont. O Império Português no Atlântico: poderio, ajuste e exploração (1640-1808). 2013. 335 f. Tese (Doutorado em História) - PPGHE/USP, São Paulo, 2003.

SIDERI, Sandro. Comércio e poder. Lisboa: Cosmos, 1978.

SLUITER, Engel. Os holandeses no Brasil antes de 1621. Revista do Instituto Arqueológico, Histórico e Geográfico de Pernambuco, Recife, IAHGP, v. 46, p. 187-207, 1967.

SMITH, Adam. Investigación sobre la naturaleza y causa de la riqueza de las naciones [1776] [Ed. de Edwin Cannan]. México: Fondo de Cultura Económica, 1958.

STOLS, Eddy. Os mercadores flamengos em Portugal e no Brasil antes da conquista holandesa. In: Anais de História. Assis: UNESP, 1973. v. 5, p. 9-54.

STRUM, Daniel. O comércio do açúcar: Brasil, Portugal e Países Baixos (1595-1630). Rio de Janeiro: Versal, 2012.

TORRES, Manoel Agostinho Madeiras. Descripção histórica e econômica da villa e termo de Torres Vedras. In: História e memórias da Academia Real das Sciencias de Lisboa. Lisboa: Academia de Sciencias de Lisboa, 1819. T. 6, Parte 1, p. 12-138.

TRATTATI DI PACE conclusi in Utrecht l'anno MDCCXIII fra'l Re Cristianissimo, la Regina della Gran Bretagna, gli Stati Generali d'Olanda, Il Re di Prussia, Il Re di Portogallo, e Il Duca de Savoja... Venezia: Luigi Pavino, 1713. 
VARNHAGEN. História Geral do Brasil. 5. ed. São Paulo: Melhoramentos, 1956. v. 5.

\section{WÄTJEN, Hermann. O dominio colonial hollandez no Brasil. São Paulo: Companhia} Editora Nacional, 1938.

\section{Notas}

1 Agradeço aos colegas Maximiliano Mac Menz, Daniel Strum, Thiago Krause, Natalia Tammone, Thiago Dias da Silva e Luís Otávio Pagano Tasso pelos comentários e sugestões.

2 "Carta régia, abrindo os portos do Brasil ao comércio estrangeiro", 28 jan. 1808, publicada, entre outros locais, por BIKER (1878, p. 102). Pela importância, registro a publicação de Hipólito da Costa no CORREIO BRAZILIENSE (2001, v. I, p. 176A e corrigida na p. 253).

3 A bibliografia sobre o tema é ampla. Registro, apenas para uma visão de conjunto, a obra organizada por CARDOSO; MONTEIRO; SERRÃO (2010).

4 José Jobson de Andrade Arruda defende que a abertura "de fato" dos portos teria ocorrido a partir de 1800 pela ação do contrabando inglês, o que, em nossa opinião, não anula a importância de 1808 (ARRUDA, 2008, p. 114).

5 Destaco que, para o tema tratado neste artigo, é irrelevante se a abertura dos portos já estava acordada com os ingleses ou a possivel influência de José da Silva Lisboa, o futuro Visconde de Cairu, para a adoção da medida. Sobre o episódio, veja-se, entre outros: VARNHAGEN (1956, p. 89), OLIVEIRA LIMA (1945, p. 209), PINTO DE AGUIAR (1960) e o livro organizado por OLIVEIRA; RICUPERO (2007).

6 Para simplificar, vamos nos referir a José da Silva Lisboa sempre pelo título de Visconde de Cairu, ainda que este tenha the sido outorgado posteriormente.

7 A dedicatória é datada de 24 de junho de 1808. Escrita provavelmente por iniciativa própria, a obra recebeu patrocínio real, tendo sido publicada pela Imprensa Régia, e ainda the valeu a encomenda de um segundo trabalho, "Observações sobre a prosperidade do Estado pelos liberais princípios da nova legislação", de 1810 (LISBOA, 1993 [1810]).

8 Rubem Borba de Moraes e Ana Maria Camargo registram o seguinte comentário: “Dizia seu filho [de Cairu] que um comerciante português, ao terminar a leitura, grafou no livro a frase: 'é réu de estado, merece a pena capital" (1993, p. 10). Registro que é incorreta a informação, dada por Hipólito da Costa e outros, de que este seria o primeiro livro impresso no Brasil.

9 Tal louvação the valeria uma crítica furiosa por parte de Hipólito da Costa, que entendia a abertura dos portos como inevitável. Para este autor, o governo, ao permitir "que os brazilianos usassem de seu direito de comerciar, não thes fez nenhum bem positivo, simplesmente se absteve de cometer um crime que até aqui praticava" (ROCHA, 2001 [1808/9], p. 63, 67). A crítica à obra de Cairu foi publicada no CORREIO BRAZILIENSE (2001 [18081822], v. 2, p. 474; v. 3, p. 49; v. 5, p. 604, 608).

10 Não sem razão, Cairu temia ser acusado de "anglomaníaco" e, curiosamente, o próprio Hipólito da Costa, escrevendo de Londres, censurou-lhe os excessos cometidos com relação a este tema (CORREIO BRAZILIENSE, 2001 [1808-22], v. 3, p. 54).

11 As críticas aos ingleses, já presentes no século XVIII, ganhariam intensidade no XIX. Exemplos desse discurso podem ser vistos na coletânea organizada em (CASTRO, 1974); ou ainda no trabalho anônimo (MALES QUE TEM RESULTADO, 1840). Sobre a preponderância inglesa, remetemos aos estudos de FISCHER (1984) e SIDERI (1978). 12 O tema do contrabando será tratado adiante.

13 Não temos a pretensão aqui de tentar sintetizar a evolução do pensamento sobre o sistema colonial e sua relação com o pensamento econômico da época. Sobre o assunto, veja-se NOVAIS (1995), especialmente o capítulo II. Dentre outros trabalhos, indicamos também HECKSCHER (19430, KNORR (1963), JOHNSON (1961) e MIMS (1977).

14 Ver também BRAUN (1989, p. 30).

15 Cairu manterá a ideia de suspensão, pelo menos até 1818. Por outro lado, é curioso perceber as várias formas do autor de definir a situação. Assim, podemos encontrar expressões como "antigo sistema colonial", "sistema colonial antecedente", "novo sistema de comércio". Cf. ROCHA (2001 [1808/9], p. 123, 168, 172), LISBOA (1993 [1810], p. 427) e LISBOA (1940 [1818], p. 66). 
16 Os resultados do Congresso de Utrecht foram sistematizados em uma série de tratados bilaterais. Os tratados de Portugal com França e Espanha foram publicados pelo Visconde de Borges de Castro (1856, t. 2, p. 234). Para um conjunto de tratados entre as várias potências, ver TRATTATI DI PACE (1713).

17 "Nota de Robert Walpole e contra-nota", seguidas de vários documentos sobre o tema de 1772 e de anos seguintes (BNL, Pombalina, Cód. 638, fl. 207, 210, 217, 220, 228v). Sobre o assunto, ver também o (Cód. 637, fl. 48) e seguintes, que repete em parte o material do códice 638 (fl. 207 "Apresentação do material", fl. 210 "Nota" de Walpole, fl. 217 "Contra-nota", fl. 220 "Demonstração" (da Contra-nota), fl. 228 "Apendix" com as leis citadas, seguidas de outros documentos). Trata-se, em ambos os códices, de uma espécie de versão preliminar, que serviria de base à versão definitiva.

18 A título de exemplo, o próprio verbete "Colonie" em SAVARY (1723), além de Hugo Grotius e Montesquieu, para citarmos os mais conhecidos.

19 Ideia que aparece de forma enfática na abertura do texto que acompanha a "Contra-nota": "Demonstração da impossibilidade moral que obsta aos navios estrangeiros de todas as nações (ainda que sejam amigas e aliadas) para serem recebidos nos portos dos domínios ultramarinos de Portugal..." (BNL, Pombalina, Cód. 638, fl. 220v). 20 As citações do texto do Marquês de Pombal, salvo indicação em contrário, são do códice 638 citado acima (BNL, Pombalina, Cód. 638, fl. 217v).

21 Sobre a ideia de "leis fundamentais", ver MONTEIRO (2005, p. 230) e a bibliografia aí indicada.

22 "Carta de 5 de abril de 1769", de Francisco Xavier Mendonça Furtado para o Marquês de Lavradio (MENDONÇA, 1960, p. 80, 82).

23 A lei publicada nas Ordenações Filipinas é uma versão ligeiramente ampliada da lei precedente. Cf. "Das penas que haverão os que sem licença d'El Rei forem, ou mandarem à Mina, ou qualquer parte de Guiné..." (ORDENAÇÕES MANUELINAS, Liv. 5, Tit. 112, 1984, p. 324) e “Dos que sem licença del Rei vão, ou mandam à Índia, Mina, Guiné ..." (ORDENAÇÕES FILIPINAS, Liv. 5, Tit. 107, 1870, p. 1253).

24 Carta sobre o mesmo tema, embora assinada pelo monarca, seria enviada no mês seguinte para o Conde de Povolide, governador da Bahia, com uma cópia da coleção das leis e ordens contra o comércio estrangeiro no Brasil. Registre-se, contudo, que as duas coleções apresentam alguma variação. Biblioteca Nacional do Rio de Janeiro (COLEÇÃO DAS LEIS E ORDENS..., Cód. 07, 1, 006). Agradeço a Valter Lenine Fernandes a verificação dessa informação.

25 No comentário aos capítulos 48, 49 e 50, o autor fará um pormenorizado histórico das leis e ordens expedidas sobre a questão, bem como tratará das questões e das dificuldades colocadas pela aplicação destas leis. "Comentários de D. Fernando José de Portugal ao Regimento do Governo Geral do Estado do Brasil dado ao mestre de campo Roque da Costa Barreto" de 1806, (MENDONÇA, 1972, v. 2, p. 739, 820).

26 Cf. Marcello Caetano "Introdução" ao livro de frei Serafim de Freitas (1960). Cf. ainda MERÊA (1924, p. 5) e HAMILTON (1948, v. 38, n. 2, p. 33).

27 "Despacho de el-rei a Rui Fernandes" de 2 de maio de 1534 (CARVALHO, 1909, p. 63).

28 O novo título completo era: "Rei de Portugal e dos Algarves, d'Aquém e d'Além-mar em África, Senhor da Guiné e da Conquista, Navegação e Comércio da Etiópia, Arábia, Pérsia e Índia".

29 A obra foi escrita contra o trabalho de Hugo Grocio, que tinha sido publicado sem autoria e apenas parcialmente em 1608 com o título de "Mare Liberum". Registre-se que a obra de Grocio ganharia fama durante a polêmica travada entre ingleses e holandeses, após a Inglaterra ter proibido a pesca aos estrangeiros nos "mares britânicos" em 1609 (FREITAS, 1960). Cf. KANTOR (2007 [ou 2005?], p. 260).

30 Sobre o tema, remetemos ao nosso trabalho (RICUPERO, 2008, cap. 3).

31 "Carta de Diogo de Gouveia para D. João III" de 29 de março de 1532 (CORTESÃO, 1956, v. 1, p. 149).

32 Salvo os casos de produtos sob estanco régio, como, por exemplo, o pau-brasil.

33 A participação estrangeira evidentemente não ficou restrita ao comércio. São conhecidos casos de europeus, de várias procedências, que se transferiram, permanentemente ou não, para o Brasil. Dentre estes, encontramos desde aventureiros e mercenários a senhores de engenhos.

34 Exemplos notórios são os Schetz, em São Vicente, e Lucas Giraldes, em Ithéus. Cf. CORDEIRO (1945), RAU (1968, p. 75).

35 Sobre o tema, ver SLUITER (1967, v. 46, p. 187), SOLTS (1973, v. 5, p. 9), EBERT (2008), COSTA (2002), STRUM (2012).

36 Registre-se que muitas vezes os navios alemães seriam na verdade navios holandeses disfarçados.

37 Sobre o assunto, ver BERGER; WINZ; GUEDES (1975, v. 1, t. 2, p. 475) e o recente trabalho de FRANÇA e HUE (2014). 
38 Para a discussão sobre se as medidas restritivas tomadas pela Coroa Espanhola foram o elemento impulsionador da navegação holandesa para o ultramar ou não, defendidas respectivamente por P. J. Blok e Georg Preuss, veja-se o trabalho clássico de Hermann Wätjen (1938, p. 66).

39 "Foral da Capitania de Pernambuco" de 24 de setembro de 1534 (CHORÃO, 1999, p. 23). Optamos sempre pela adaptação das citações ao português moderno.

40 O rei, no regimento dado ao provedor-mor, expressava-se: "Hei por bem e mando, que todas as naus e navios que de meus reinos e senhorios ou de fora deles forem as ditas terras do Brasil...". Cf. Regimento do Provedor-mor da Fazenda de El-Rei Nosso Senhor destas partes do Brasil (1548) (DH, v. 13, p. 39, 47, 54).

41 Por outro lado, a lei fazia expressa menção à possibilidade de apresamento de navios estrangeiros, desde que sem licença, no Brasil e Costa da Guiné. Ver a referida lei em Agência Geral das Colónias (1943, p. 14, 22).

42 Neste sentido, discordamos da interpretação dada a esta lei por Almeida d'Eça (1921, p. 126) e Arthur Cézar Ferreira Reis (1960, v. 2, p. 312).

43 Vejam-se os diversos alvarás e cartas régias publicados no primeiro volume (DHA, 1956).

44 "Regimento de 17 de setembro de 1577 sobre a arrecadação dos tributos do açúcar e demais frutos da terra" (DHA, 1956, v. 1, p. 279, 284).

45 No âmbito deste trabalho, não teria sentido descrever a conjuntura político-militar europeia, mas registrese apenas que a luta da Coroa espanhola pela manutenção do domínio dos Países Baixos ganharia um novo desenvolvimento com a declaração de independência das Províncias Unidas (Holanda) em 1581; que as hostilidades abertas com a Inglaterra, na década de 1580, acabariam provocando a guerra entre os dois países, com o famoso episódio da "Invencivel Armada" em 1588, e que a intervenção espanhola na França provocasse uma nova guerra com esse pais a partir de 1589. Dentre a imensa bibliografia disponivel, indicaremos apenas a sintese de ELLIOTT (1976) e duas obras especificas para o momento: CLARK (1985), RODRIGUEZ-SALGADO e ADAMS (1991).

46 "Alvará de 9 de fevereiro de 1591 proibindo o comércio com estrangeiro" em DHA (1956, v. 1, p. 379).

47 Tal medida se repetiria em 1595 e 1598 (sob Filipe III). Esta, nas palavras de Engel Sluiter, "a mais impetuosa das capturas de embarcações holandesas". No começo do século XVII outras medidas visando o comércio holandês seriam tomadas. (SLUITER, 1967, p. 193) Ver também FREITAS (1960, p. 18) e STRUM (2012, p. 291). A Carta de Filipe II de 29 de maio de 1587 pode ser vista na obra de MIRAFLORES e SALVA (1867, t. 51, p. 18).

48 Para Virgínia Rau, só em Lisboa e Setúbal teriam sido apreendidos cem navios holandeses, fora outros ingleses e alemães. Virgínia Rau (1984, p. 152). Para outros números e para a reação a tais medidas ver a citada obra de Engel Sluiter.

49 As obras citadas abaixo atestam a participação de João de Teive nos negócios ligados à Fazenda Real. Manoel Torres nos informa que "João de Teive Contador Mor que foi destes Reinos por espaço de 36 anos", atuando em "Negócios de grande confiança [junto] aos Reis D. João o III, D. Sebastião, D. Henrique, D. Filipe I e ao II e III, deste nome, sendo do Conselho destes últimos" (TORRES, 1819, t. 6, p. 70; RIBEIRO, 1826, parte 5, p. 5).

50 "Carta de João de Teive, sobre o dano que recebe nos direitos e fazendas de Sua Majestade no comércio de Estrangeiros no Brasil" de 9 de setembro de 1587 (CORTESÃO, 1956, v. 1, p. 28).

51 Entendemos que tal provisão seria uma entre as várias emitidas no período que tentavam regulamentar o comércio e coibir as fraudes. Vejam-se os diversos alvarás e cartas régias publicados em DHA (1956, v. 1).

52 "Regimento que se deu a Balthezar Roiz Soza, provedor-mor da Fazenda do Brazil" 12 mar. 1588 (RIHGB. Rio de Janeiro: IHGB, 1906, t. 67, parte I, p. 215).

53 Seria, segundo Sluiter, um navio mercante zelandês que desertou para o lado de Withrington (1967, p. 202). Cf. BERGER; GUEDES; WINZ (1975, p. 493).

54 "Treslado do Regimento que levou Francisco Giraldes que Sua Majestade ora mandou por governador do Estado do Brasil" de 8 de março de 1588 publicado na RIHGB (1906, t. 67, parte 1, p. 220) e em DHA (1956, v. 1, p, $225,355,362)$. Sobre a ação e os regimentos dos governadores-gerais, ver COSENTINO (2009).

55 O exclusivo metropolitano, como vimos, não se limitava à proibição da presença de mercadores ou navios estrangeiros nas colônias e, neste documento, não se faz menção da restrição à possibilidade, até então permitida, do envio de navios portugueses para outros reinos.

56 "Provisão expedida da Bahia, pelos governadores do Brasil - Cristóvão de Barros, Antônio Coelho de Aguiar e o Bispo -, designando, em 1589, Lopo Fernandes, que aqui servia de meirinho do mar, para o ofício de guarda mor do mar" de 3 de outubro de 1589, publicada em PRADO JR. (1928, v. 3, p. 134) e descrita por LISBOA (1834, v. 1, p. 303).

57 Este só chegaria ao Brasil em junho de 1591. Cf. "Treslado do Regimento que levou D. Francisco de Sousa" 
de 5 de dezembro de 1590 (BNL, Pombalina, Cód. 644, f. 292v). O regimento é quase uma cópia literal do anteriormente dado a Francisco Giraldes, exceto, em especial, o item que trata do comércio com o estrangeiro. Registre-se que, ao que tudo indica, esta versão também seria a base do regimento de Diogo Botelho de 1602 58 Morador no Brasil, tendo servido como provedor da fazenda e em outros cargos.

59 BNL, Pombalina, Cód. 644, f. 114v "Cópia do parecer da junta sobre coisas do Brasil que foi a Sua Majestade" de 1 을 de dezembro de 1590 .

60 "Alvará de 9 de fevereiro de 1591 proibindo o comércio com estrangeiro" (DHA, 1956, v. 1, p. 379).

61 É apenas na parte da punição aos que não cumprirem o Alvará que se associa a nova lei com as antigas contidas nas Ordenações do Reino, o que, como vimos, ajudaria a confundir as duas situações.

Curiosamente no regimento dado ao licenciado Baltazar Ferraz, para cobrar o que se devia à Fazenda Real, três dias depois da promulgação do Alvará de 1591, não se menciona a proibição do comércio, apenas orientava: "que sabereis por inquirição devassa que tirareis em que forma se arrecadam os direitos e se se guarda a ordem e faz verdade nas avaliações das mercadorias que vão de fora do reino, que por obrigação hão de pagar dízima por entrada e a maneira e vigia que se teve nos navios que carregam nessas partes açúcares para fora do Reino, e como se faz a avaliação deles para a dízima que haviam de pagar por saída à minha fazenda", passando apenas as instruções dadas a Baltazar Rodrigues de Sousa em 1588, vista acima, para o passado: "tem" para "teve" e "hão" para "haviam". Ver "Regimento que foi dado ao licenciado Baltazar Ferraz pera cobrar o que se deve a Fazenda de S. Magestade" 12 fev. 1591 (RIHGB, 1906, t. 67, parte I, p. 237)

62 Para Vera Ferlini, "o compasso de euforia criado pelos incentivos do início da colonização manteve-se até a década de 1610" (1988, p. 63). Sobre o assunto, ver RICUPERO (2012, p. 337).

63 Contrapondo "estrangeiro" aos "naturais da terra", o autor parece incluir os moradores de Portugal na primeira categoria.

64 Os riscos do contrabando atestariam indiretamente a alta lucratividade do comércio colonial. Ainda que posterior, a passagem de Dunning citada por Marx poderia bem ilustrar a situação: "com lucro adequado, o capital cria coragem. Dez por cento certos, e fica assegurado seu emprego em qualquer parte; com $20 \%$ infla-se de entusiasmo; com $50 \%$ é positivamente audacioso; com 100\% calca a seus pés todas as leis humanas; e com $300 \%$ não se detêm diante de nenhum crime, mesmo sob o risco da forca" (1989, v. 2, p. 879).

65 Cf. "Provisão para os mercadores fretarem as duas urcas que vão ao Brasil levar o governador D. Francisco de Sousa, possam carregar sem embargo da provisão". Lisboa, 6 de março de 1591 (BA, Cód. 51-VI-28, f.20v). Uma provisão com o mesmo teor, mas com outra data, pode ser vista na coleção de "Documentos mandados copiar pelo Senhor D. Pedro II" (RIHGB, 1906, t. 67, parte I, p. 68).

66 O chamado "Livro das saídas dos navios e urcas" registra 34 casos, entre 1595 e 1605, de navios, na maioria "alemães", saídos de Pernambuco que não teriam cumprido as regras estabelecidas, e, portanto, os fiadores das licenças poderiam ser obrigados a prestar conta dos direitos alfandegários (MELLO, 1967, p. 21).

67 Por exemplo, "Ordem ao provedor dos Armazéns para que obtivesse navio, mesmo estrangeiro, em que pudesse passar ao Brasil seu novo governador, D. Luís de Sousa" de 1616 (LISBOA, 1958, p. 129).

68 Estamos chamando de comércio clandestino, para diferenciar do contrabando, por exemplo, o comércio feito por navios estrangeiros disfarçados de portugueses. Assim, para Strum, "era preferivel arcar com os custos de uma intermediação portuguesa e usar fraudes condescendidas, como a camuflagem e o rebatismo, a afrontar as autoridades com a ilegalidade absoluta" (STRUM, 2012, p. 291-315).

69 Evidentemente não cabe, nos limites deste trabalho, uma tentativa de reportar os inúmeros casos registrados. Assim, limitar-nos-emos a descrever alguns episódios que ajudam a perceber a crescente repressão ao comércio estrangeiro.

70 Seria temerário tomar as palavras de Frei Vicente como prova definitiva do fim de tais viagens, mas, ao usar o passado "costumavam vir", o autor claramente indicava que a frequência de tais navios, no mínimo, era então significativamente menor.

71 Sobre o assunto, ver "Carta do rei para Diogo Botelho" 30 ago. 1606 (RIHGB, 1911, t. 73, p. 20; MAURO, 1963, p. 223).

72 Os sobreviventes estavam presos em Salvador na altura do ataque. Sobre esse ataque, ver BERGER; WINZ; GUEDES (1975, p. 505) e o relato de Frei Vicente do Salvador (2008, fl. 137).

73 Como em outros episódios, as negociações com barcos estrangeiros poderiam se transformar na captura do barco ou em ações de pirataria, dependendo da correlação de força entre as partes.

74 Lembro que o transporte em navios estrangeiros não implicava necessariamente a exclusão dos mercadores portugueses do negócio, pois tais embarcações transportavam, no todo ou em parte, cargas de mercadores ou 
produtores portugueses, associados ou não aos estrangeiros. Vide o citado "Livro das saídas dos navios e urcas". 75 A ênfase dada por Celso Furtado aos capitais flamengos na montagem da economia açucareira é, em nossa opinião, excessiva (1991, p. 10, 11). Analisando o caso do Rio de Janeiro, João Fragoso afirma não ter encontrado evidência empírica para a hipótese de Celso Furtado (FRAGOSO, 2001, p. 37).

76 Novais, comentando as concessões feitas por Portugal nos tratados firmados com a Inglaterra e a Holanda no pós-Restauração, explica que o que se concede "é no fundo a participação desses países no usufruto da exploração do sistema colonial português" (NOVAIS, 1995, p. 81, 91).

77 Sobre o tema, ver CAVALCANTE (2006).

78 Registro ainda que o regime de frotas, as companhias privilegiadas, os estancos e o sistema espanhol de "porto único" no comércio com a América seriam formas de restringir ainda mais a concorrência e, consequentemente, aumentar os lucros.

79 A Coroa, interessada na receita alfandegária, revogou a licença. Cf. "Representação do Conselho da Fazenda" de 1655 (ANTT, Miscelâneas Manuscritas, 1146, fl. 59-60).

80 Dado o escopo do presente artigo, não temos a intenção de abordar o funcionamento do exclusivo metropolitano. Sobre a questão, ver os trabalhos de ARRUDA (1980), ARRUDA (2014, p. 706) e PEDREIRA (2014, p. 438).

81 A outra parte era formada pelos mercadores que se aproveitavam dos negócios com o Estado. "[Carta sobre o comércio de Portugal com a Itália]", de 1800, Memórias econômicas inéditas (1987, p. 286). Com introdução e notas de José Luis Cardoso.

82 "Não querem arriscar os seus capitais em outra espécie de comércio", Memórias Econômicas Inéditas (1987, p. 286). Sobre o assunto, ver também SMITH (1958[1776], p. 535).

83 Para Engel Sluiter (1967, p. 187), os holandeses, aproveitando-se da trégua dos doze anos, terminada em 1621, teriam mantido sua participação no comércio até esse ano, de forma clandestina e associados a grupos portugueses. Tal participação, em uma modalidade que poderia ficar entre o comércio com licenças e o contrabando, também não anularia o exclusivo, pois não configuraria uma situação de liberdade de comércio. Sobre o assunto, ver também Daniel Strum (2012, p. 291).

84 Pedro Puntoni destaca a rivalidade na Holanda entre um grupo mercantil "velho" com seus interesses no comércio do açúcar articulado, em alguma medida, com portugueses, e um grupo "novo", este defensor da guerra e ansioso por controlar o comércio colonial. Dessa forma, completamos, a vitória do grupo "novo" e as tentativas de conquista do Brasil contribuiam assim para enfraquecer os laços do "velho" grupo no negócio açucareiro (PUNTONI, 1996, p. 256).

85 O tema é, evidentemente, controverso, mas vários autores compartilham o entendimento de que a partir de 1605 poucos navios estrangeiros teriam navegado direto para o Brasil. Cf. COSTA (2002, p.116) e EBERT (2008, p. 167). Para Jonathan Israel, depois de 1609, os arquivos notariais de Amsterdan mostram que viagens diretas entre a Holanda e o Brasil passam a ser pouco frequentes e, citando Hermann Kellenbez, o tráfico direto entre Hamburgo e o Brasil teria cessado em torno de 1600 (ISRAEL, 1991, p. 107).

86 Sobre a exploração e destruição da mão de obra indígena, ver SCHWARTZ (1995, p. 40) e RICUPERO (2008, p. 207).

87 Ver nota 17.

88 A citação segue: "[...] a Coroa aprende a fazer os rios coloniais correrem para o mar metropolitano; os colonos compreendem que o aprendizado da colonização deve coincidir com o aprendizado do mercado, o qual será primeiro e sobretudo - o mercado reinol. Só assim podem se coordenar e se completar a dominação colonial e a exploração colonial". Neste ponto, nossa divergência com o trabalho de Alencastro é a atribuição de uma consciência plena da Coroa sobre o processo em curso. Ver NOVAIS (1995, cap. 2) e ALENCASTRO (2000, p. 11).

Rodrigo Ricupero. Professor Doutor. Departamento de História da FFLCH/USP - Av. Professor Lineu Prestes, 338, Cidade Universitária, Butantã CEP 05508-000 - São Paulo/SP - Brasil.

Recebido em 15/07/2015 
Aprovado em 05/11/2015 